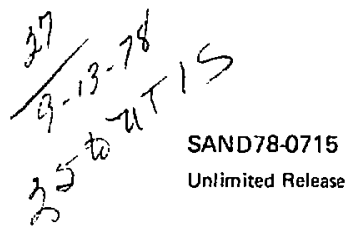

\title{
3151
}

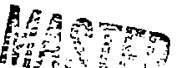

Pas

\section{Borehole Plugging-Materials Development Program}

Ciıarles W. Gulick, Jr. 
SAND78-0715

Untimited Release

Printed lune 1978

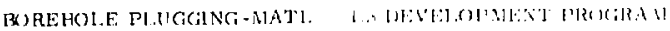

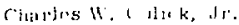

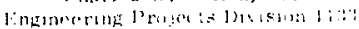

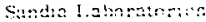

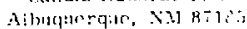

\section{A BSTRMCT}

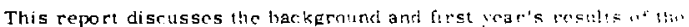

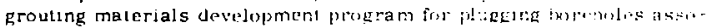

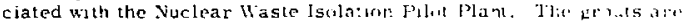

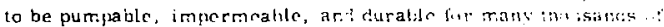

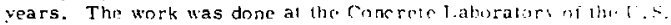
Army Enguneer Haterways Exporiment Stalun (WFS), Vukshug, Mississippi. The workability, strength, pousuty, hundere. rxpansın, and permcabilıty data aro summarizet and diseuscurt. W." work is continuing at WES.

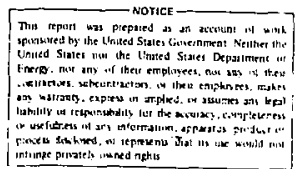




\section{ACKNOW'LED GMENTS}

The freuting materials development work was conducted hy the Concrete Laboratory of the U.S. Army Enginecr Waterways Experiment Station, Vickshurg, Mississinnt. Brvant Mather, Chiof of the Concrite Laboratory, and many members of his staff have actively partucipated in the many coordinglion meetings. J. A. Bne, Jr., under the supervisinn of $h$. A. Bendinelli, head of the Grouting Branch, has been responsible for conducling the studies and reporting the results.

The study program is lunded by the Department of Energy, Waste lsolation Pilot Plant ,.. Sandia's Waste Management Technology Department has technical responsibility. L. R. Hill and S. J. Lambert of the Nuclear Kaste Technology Division have participated incoordination meetings at WES a at in other discussions related to the program. 


\section{CONTENTS}

\section{Section}

Pagc:

II Background

III Materials Development Program at WES

T

Introduction

1

12

IV Long Term Development Plan

17

References

18

TABLES

$\underline{\text { Table }}$

$\underline{\text { Pagu }}$

I Grout Mixture Proportions and Strengths 
BORFHOLE PLUGGING-MLTERIALS DEVELOPMENT PROGRAM

1. Introduction

Representatives of Sandia Laboratories attended a Forehole Plugang Program Rrvicw meeting in July 1975, conducted by the Office of Waste Isolation (OWI) at the Oak Ridge National Laboratory (ORNL). Industrial experts and ERDA personnel reviewed the accomplishments of the program to that date.

The purpose of the program is to

- Develop techniques for plugging boreholes ihrough and adjacunt in underground waste disposal facilities

- Seal boreholes with plugs which will prevent movement ol nuids and gases toward or through the salt beds

- Provide plugs which wall maintain their integrity for time periods comparible to the life of the rock formations in which they are used.

The concensus of the review meeting was that the only material currently avallable for plugging boreholes is high-quality cement. The desired approach is to improve the cementing technology, primarily materials, to neet the stringent quality standards required for waste storage sites.

Subsequent to that meeting, a state of -the-art repor: ${ }^{2}$ for borehole plugging was completed and distributed. A second Borehole Plugging Review Conference was held in Tucson in Niveminer 1976. Again, the Ad Hoc Committee concluded that existing state-nf-the-art methods, machinery, materials, and knowledge are adequate to ensure that boreholes can se reentered and that horrhole plugs comparable to or stronger than the original rocks can be installed to provent verticat movement of fluids and gases. The committee furthes coneluded that the problem of credibility remains ard must be addressed.

In a Iftter dated January 7, 1977 in the US ERDA, Division of Waste Managemert, the Director of OWl listed three major programs for FY77 and Fi'78:

1. Cement and Concrete Research and Development. Contune io support cement research at Penn State and at ORNL. It was noted that this work is complemented by a Sandia-supported project at thi U.S. Army Engineer WES, Vicksburg, MS.

2. In Situ Borehole Plugging Demonstration Protect. 
3. Hevelop instrumentation to manitor the physical and chemical properties of the plug and wall rock materials with telemetering systems and remole power supplies for many years.

Sandia commented that several years of development are necded for the third program and its successful completion is needed for the long-range montoring of the second program to develop the erediblity needed for the Borchole Plugging Prngram.

The initial conclusions reached in 1975 were the impetus for initiating a long-rangc development wh insting program at the WES Conerete Laboratory. The program is to study and improve comentung materials and to conducl exposure tests of materials over an extended time period. This copret wll summarize the preliminary discussions and the various activilies loth in the laboratory anil dit lin. figld which have taken place in sup ort of the Borchole Plugging Devofupment Program. 11 wh anglty the first WES report of studies for the loorchole Plugging Program. 


\section{Hackground}

Discussions cotecrning plugging borcholes and durahility t.. ce minting mitrrals have birn held sine $J \cdots 1 v 1975$ with individuals from the following organzaliuns:

B. J. Hughes, Inc.

Concrete Laboratory, WES

Mowell Division of Jow Chemical U.S.A.

Haliburion Services

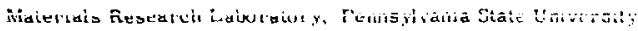

Portland Cement Association

Southwestern Portland Cement Company

U. S. Nayy Civil Engineering Laboratory

These discussions have been useful in finding previous and aterent studes about the bely: $60 \mathrm{y}$ of cementing malerials and in obtaining ideas for possible improvements.

A Dowell study ${ }^{3}$ evaluated existing materials and techniques (in (I) 73 ) to dricrinine the most suitable system for plugging boreholes. The recommended cements for the New Nexico arca were Lwo from Southwestern Portland Cement Campan; Fil Toro Type V and El Tnro Chem Comp (expanding) sulfate-resistant cement. Hoth ecinents produced excellerib tontis to furination matertais Bnd are resistant to sulate-tater. The report staled that the trend was to use expanding cerient (ChemCompl in critical areas: however, the T3urcau of Manes was dIf: only onc publisining flata to back up the statement. ${ }^{4}$ Preliminary labnratory testing reported hy the Burcau cf Mines showed lower values of porosity and permeability and kigher bulk densily fot tue chemcomp prout maxturs. than for normal portland cement and a flitash-and-portland cemont mix.

The recommended cementing material in Reference I thr the New Mexico area is a special Class $C(S R)$ cement which contauns no $\mathrm{C}_{3}$ A and, therefore. has high-sulfate resisiance. The anly two cements manufactured for the oil industry and meeting these requirements are l.one Star Cement "Incor" from Maryneal, Texas and Southwesterr. Portland Cement "El Troro 35" from. Odessa, Texas. The addition of nyash and disnersant to lower the water content are also rerom. mended.

The Portland Coment Association (PCA) conducted studics or the resistance of portland cement mortas and conerete to atlacks by sulfate and other chemicals for several decades, 5,6 The laboratory studies of mortar bars in Reference 4 showed that El Toro Type $V$ centent (calculated $C_{3} A$ content of $\left.3.7 \%\right)$ is more resistant to sulfate attack than the nucr acments. The field exposure studies ${ }^{5}$ showed that cements with less than $111^{m}, C_{3}$ A conten performed without concrete detcrioration through 25 years of exposure to sulfate soils. 


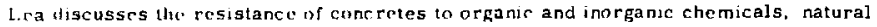
water.s, and sulfate soils. ${ }^{7}$ In addition to the importance of lnw $C_{3} A$ content to resist sulfate attack, he strosses the pozzolanic cements ta inerease resistane te chemiral attack.

Tuthill staled that, in addiuon to low tricalcium aluminale content betng the most imporiant factor in improving resistance of conerete to sthfotc, several other factors provide improvement: (1) walue wator/ecnent ratuo, (2) redure the baching of hydrated lime by using an artive pozato-

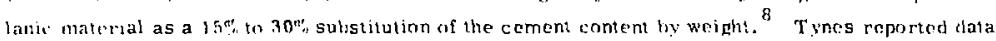

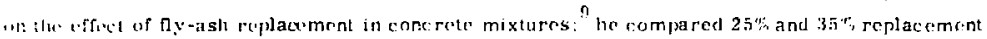

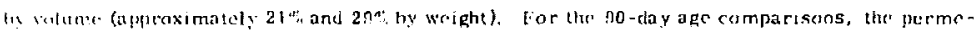
ablut was peluecd for the ny-ash-repjacement mixtures compared to the all-portantl-ecment masiar. Buth amouns nf gy ash gave abuot the same permeability while compressive strength

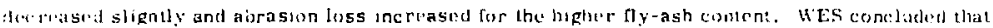

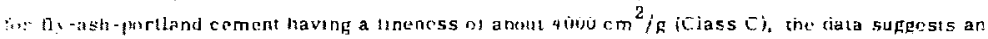
wintnan fiv-isli content of abuut 25 , by woight. 10

Hehta faund that eypansive cement corterdes made with shrinkage-componsating Type $h^{*}$

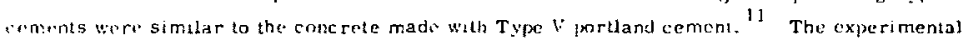
resule and theoretucal computatuns showed that the resistarce to sulfatu athatk is related to the amount of $\mathrm{Al}_{2} \mathrm{O}_{3}$ the $\mathrm{A}$ in $\left.\mathrm{C}_{3} \mathrm{~A}\right)$ avallahle

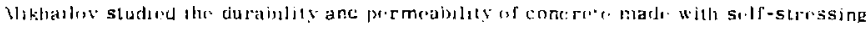

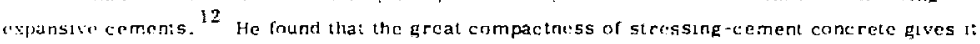

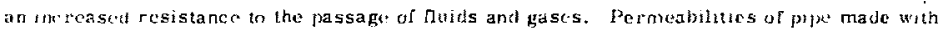
slrussing cenent wre reduced bv an order of magnitude or greater than with normal portland

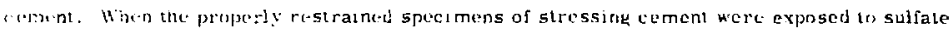

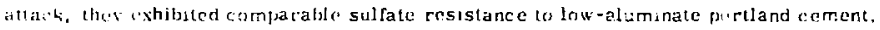

The data in the references and the discussions suggested the following approach to the pro-

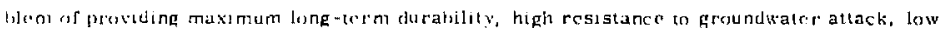

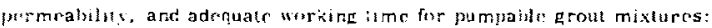

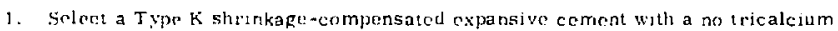

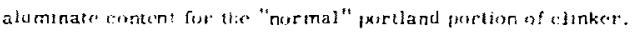

2. Include mor" highly "xpansive Type $\mathrm{K}$ self-stressing coment to possibly

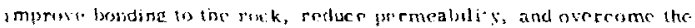

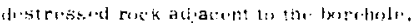

3. Ineludo both $7 y$ asi and natuat pozzolans to study their effects on permeability and durability.

4. Study water redue $2 n$ admixtures (super plasticizors) to find those most efficiont in reducing the waler/cement ralso, 
5. Include a retarder to achieve a working time or 3 nours for iny mixture stelected for extenfed lesting.

6. Add salt, both dissolved in the ritxing water and as salt sand, le some mixtures

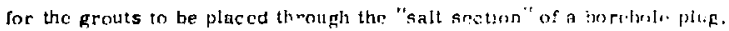

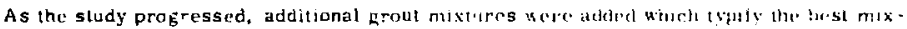
tures currently available for the soulhwest New Mexico a rea - (Inss C (SRR) (en ment. Beth latwora-

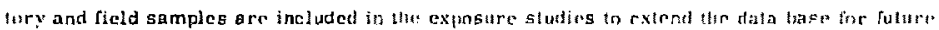
der ons whenever a borehole is to the permanently plugget.

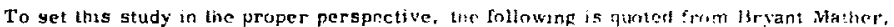

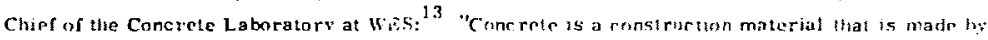

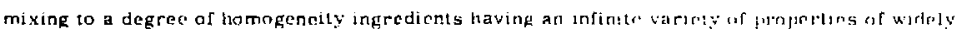

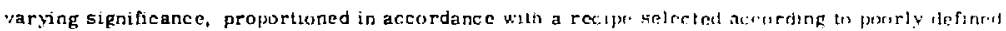
rules." The same idea is applicable th grouts in the cementing industry. Even with the latge a mount of laboratory research including techniques in simulalu conditions und rarnund, the prescrt knowledge of actual behavior in situ is still far from enmplete. The goal of the Brireirle fougging Materials Development P.ogram is to

1. Combinc an extensive laboratory program with lield supervisinn and quality control of grouting uperitions

2. Continue study cif representative field samples of grout mixtures including samples prepared at the surface and, when possible, cores of the downhole plugs. 


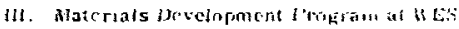

The mitul phase of the wirk at WLS consisted of proportunang soveral hundred grout mix -

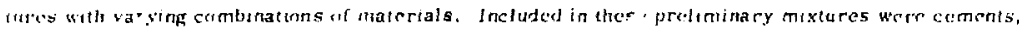

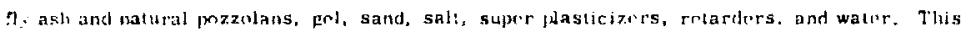

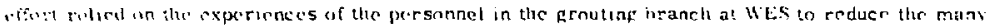

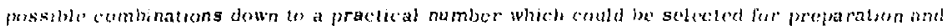

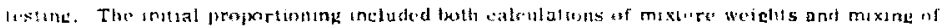

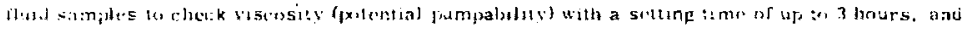

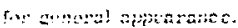

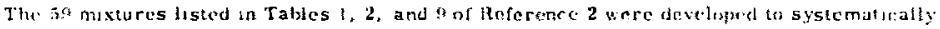

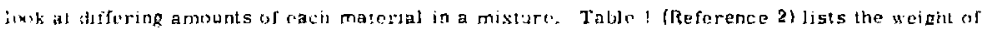

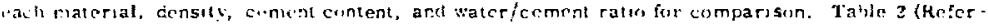
.the 2) lists the freshly mixed and hardened data. The hehavior in the freshly mixcd stakyvisousily and tine of initial and final set-provided data fur selectun uf mistures fur furthes

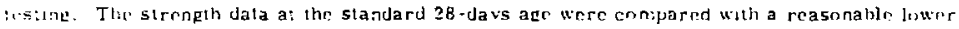

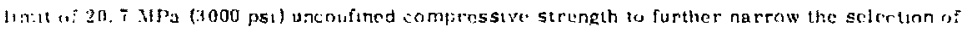
mixtures. This strength lovel is comparable to the expected upper level of in situ conditions for

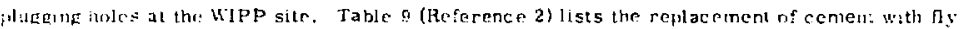

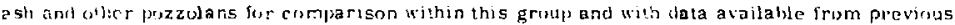
Elaties at WES ant rlsewherr.

As soon as most of thrse data werc available. the mixlures fur long-term durability and

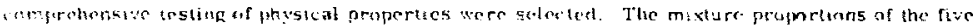

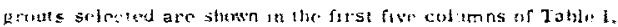

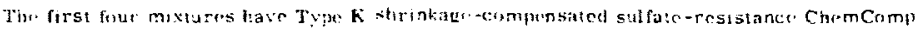

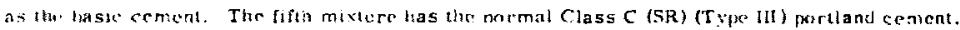

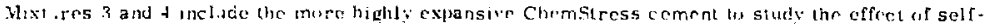

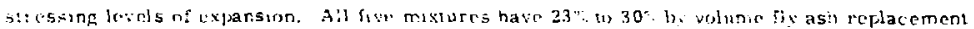

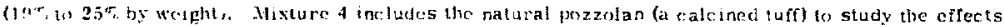

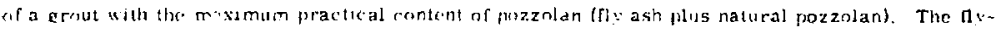

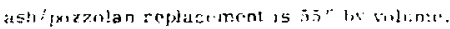


TAII E: I

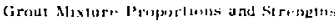

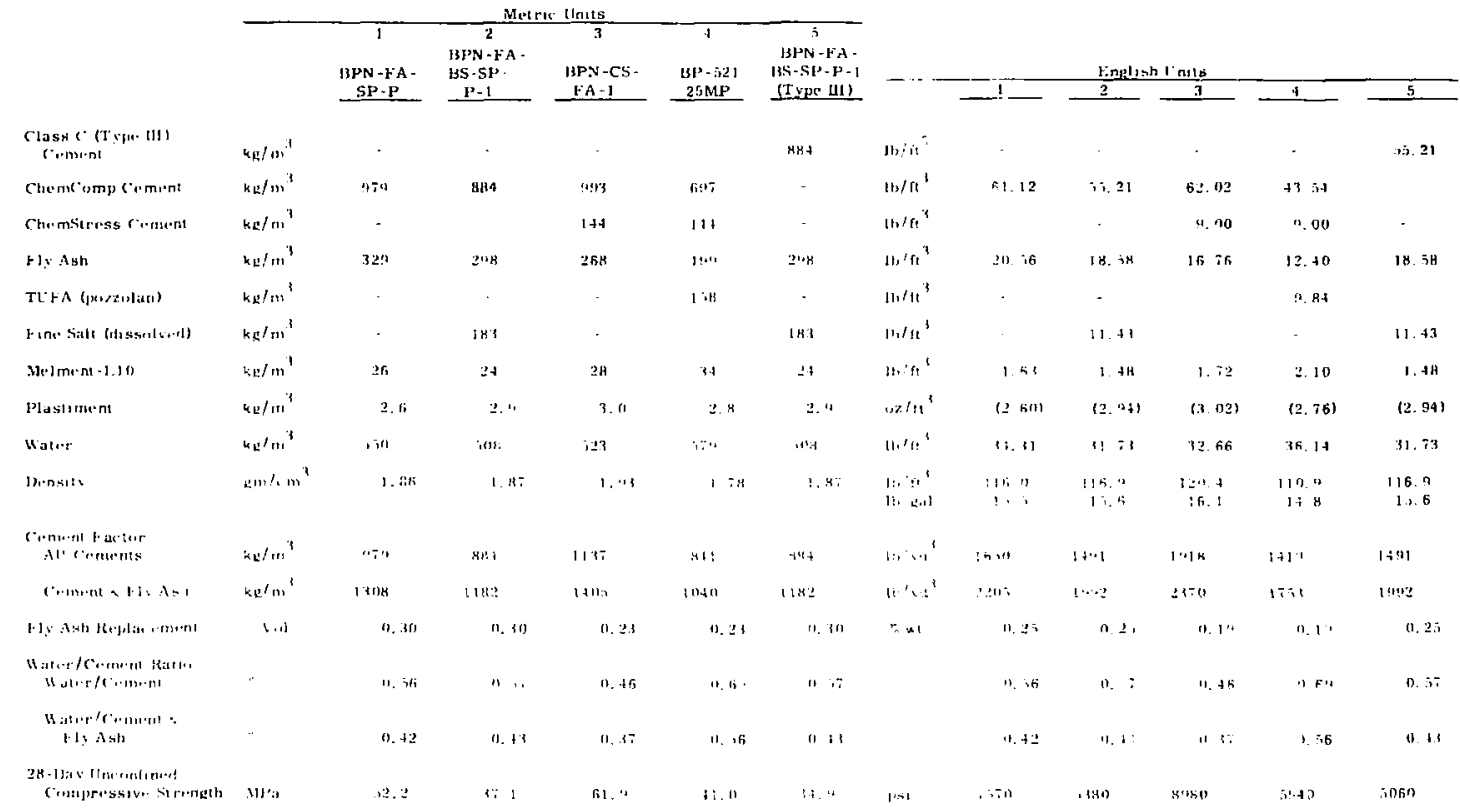


Mixtures 2 and 5 used saturaled brine mixing water. Mixture 2 is a direct comparison with Mixture 1 to study the effect of saturated-salt grouts which may be required through the salt sections of borehole plugs. The effect on strength is notable for the same water/cement ratio. The reduction in the unconfined compressive strength from $52.2 \mathrm{MPa}$ to $37.1 \mathrm{MPa}(7570$ psi to $5380 \mathrm{psi}$ or $\left.23^{*}\right)$ is probably more severe titan the reduction in cement content of 10 percent for Mixture 2 compared to Mixture 1 witli fresh water.

Alf five mixtures have the superplasticizer Melment L-10 included to reduce the water content to the minimum whila still mantaining adequate pumpability. This is expreted to improve strength, bonding, and durability, and to reduce permeability. The addition of the retarder, Plastument, maintains the pumpability (for these high-cement-content grouts) for the required 3 hours.

Mxiture 3 had the highest Muid density of all the grouts withut salt or sand in the mixture. It also had the highest 28 -day unconijned compressive strength. The highest cement content and lowest water/cement ratio accounts for this vrry high strength which is not normally found in pumpable nixtures.

A comparison of ChemComp cement wilh Class C (SR) (Type lll) cement in brine grouts can be seen in Mixtures 2 and 5 . With all weights of materials be'ng equal, the strength for Mixture 2 is about 6 greater.

Some of the specime:is of each of the five mixtures have been submerged in water with a chemical content similar tc the underground water samples of the WPP site. The first criteria and method of preparation for the simulated groundwater are listed in Table 8 (Reference 2). The crileria was revised as listed in Table 10 (Reference 2), to simulated groundwater for the exposure and permeability testing after the first year of exposure for the current specimens.

The remainder of this section will discuss the data in Tables 3 through 7 (Reference 2). All of the data and observations of the specimens confirn: the excellent quality of the five selected laboratory mixtures. There is no apparent deterioration of any specimen either under the exposure to simulated groundwaler or protected to prevent moisture loss in the laboratory environment.

Table 3 (Reference 2) Jists dynamic modulus and compressional - wave velocilies for $7,6-\mathrm{cm}$ -

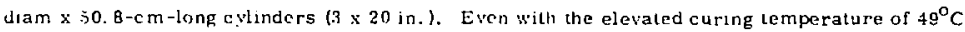
(120\% $\mathrm{F})$ for 28 days, the initial representative values fur mixtures with $30 \pi_{0}$ or higher pozzolan content should be the 56 -dayt age values. Mixture 3 consistently has the highest unconfined compressive strength, the highest dynamic modulus, and the highes compressional-wave velocity. Converselv, Mixture 5 has the lowest values. The ather three mixtures have consistent numbers based within that range consistent with the relative strengths. The variation in dvnamic modulus from 56 days to one year for the same exposurc conditinn is less than 5 w, and generally has a slight uncreasing trend as expecled for the continuing normal hydration of the cement content of the grout. 
The highest value is $23.6 \times 10^{3} \mathrm{MPa}\left(3.4 \times 10^{6} \mathrm{psi}\right)$ for Mixture 3 with the highest strength. The lowest values are about $13.8 \times 10^{3} \mathrm{MPa}\left(2,0 \times 10^{6} \mathrm{psi}\right)$ for the two lowest strength mixturis, 2 and 5. These are the two mixtures with saturated-salt mix water.

The compressianal - wave volocity data show a similar pattorn of the highest values for Mixture 3. The variation with tume for each mixture is Jess than 5 "to and dues not show an ineroasing trend for all mixtures at later ages. This variation is alout the expecterl aceuracy of the suriscope for the $51-\mathrm{cm}$ (20 in.)-long specimons.

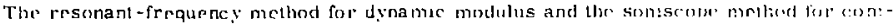

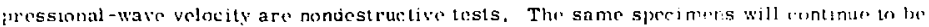
iested al l-year intervals to monitor improvement or deteriorateon. There are thren specimens

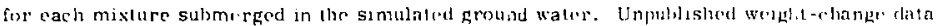

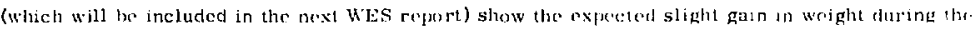

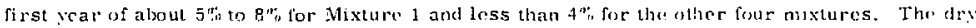
specimens were covered with a plastic cuating at denuslding and encasesl in douhli-plastie baus to prevent moisture loss. The wrighi loss is less than for for these spesimens, most of which pre:bably occurs when they are removed from the plastuc hags for periodic measurements.

All of the above data indicate good quality grout with no evidene of deterioration during the first year of exposure to the simulated groundwater.

The bond-strength data in Tablo 4 (Reference. 2 ) was ultended to provide a preliminary indica: ion of bonding characterisucs for each of the mixtures. The test of bondir.p to a smooth stecel surface is probably more severe than the bonding to rock with iregular surfactes. The values of bond strength which range between $5, \Omega$ anri $1.7 \mathrm{MPa}(85.5$ and $250 \mathrm{psu}$ show a good tught inter face. Tho successive cutting of specinens from the grout-filled pupe and drung of the grout can explan tile lack of definte trends. The current bond studies are coneentrating on bonding to the formation materials.

In Reference 3, bond strengths of grouts to sandstone, sali, and anhycrite were detirmuned.

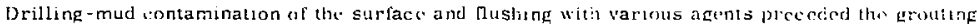

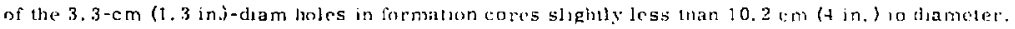
Values of bond strength to sandstone were 2. B MPa to about 8. 4 a Xll'a (400 to 1225 psi). Snme of the five study grout mixtures may show higher values of bonding to the simgor fornation rocks

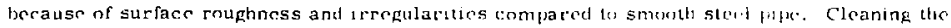

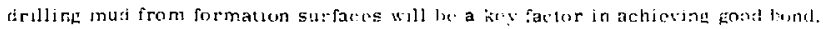

The volume-change data in Table 5 (Reference 2) is a measurement of the lergtis change of unrestrained $0.075=x 0.075-x 0.25-m(3-x 3-\times 10-i n$.) prisms. The set of specimens coated with a protective "paint-on" skin and stored in doublu-plastic hags at 24 -hour agc still show a "drying nut" Jeng(l) reduction for all five mixtures. Mi:ture 3 with ChemStress expansive cement showed 
a peak expansion at 14 -day age and had the least length reductuon of all five mixtures. The other nuxture with shemstress and witli the additional natural pozzolan (Mixture 4) reachad a lower peak ixpansion of 6 days and showed the aexl lowest length roduclion through 6 months, Mixture 5 with brine $n^{+1}$ xing water and the normal Class $C$ (SR) cement showed a sligm expansion through 3 days and a slightly ferater length redurtion through 6 months than Mixture 4 . Mixtures 1 and 2 showed no expansion and about sor"griatir length reductions than the other three mixtures through 6 months age. Tie data for Mixtures 1 and 2 show a continuing length reduetien through 12 months ut data.

The serond sel of speciniens which had the initial Jength reading after remaining in the stect molds for 28 days were then submerged in the simulated frollndwater. Muxture 4 kept its initial length theouph 6 monihs. Mixture 2 (w'th brine mixing waler) s'usued the greatest expansion for the submreged spectmens. All of the expansions stablized ly finnths and have maintained the Ionglh through 12 months. There is mapparent deterioratinn of the surface of these submereed samples. The effect of the expansion on lond strength will be evaluated during the tond-toformalur: testing sunce a definitive trend for tho bond-to-sterl pipe specimens is nol upparent at this umé.

Boa concluded that the data on porosity may be misleading since Mixture 5 had the lowest porosity and was the only mixture which had a neasurable permeability for flow through the spectmen. All mixtures had waler now intially into the specimens. Mixtures 1 through 4 showed permeability rates of less than 0.0002 md during the initial fow of water into the specimens through about 1 to 2 weeks time. The data for Mixture 5 in Table 7 (Reference 2 ) shows permeabilities $0: 0.0006$ md and less for the four specimens. The exective porosity is receiving additonal study. Gas permeabulity testing of samples has recently heen initiated; also porosily determinalions by grinding of spceimens to a finc grain size and comparison with the pressure mycnometer data in Table 6 (Reference 2 ) are underway. These studies will receive more emphasis during the current vear and will be diseussed further in the noxt report. 


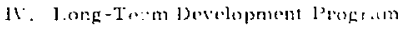

The studes at WES and numerous discussıons wath ondividuals haw genemater uras for the

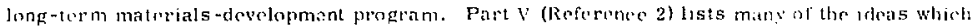

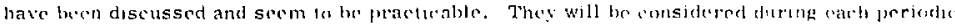
revinw of work in porgess and in planning for the grogram.

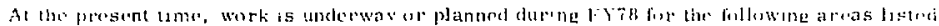

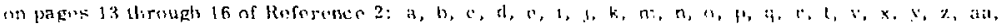

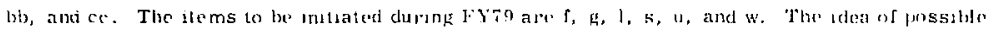
use of chemeal matching grout (item $h$ ) is not being activoly pursued untor this progtram. Itom Oror, WES maintains an up-tu-date knowlodge of chomeal grouts avilable thenughout whe worle! fo: thes many other RND programs. Now products with propertues which scom advantagentus will be discussed at perindic reviow meetings.

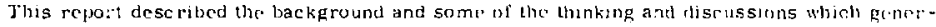
at id the Nork underway, the data available, 2 and a list of activilies proposed for initiatusn during the nest yoar and a bals.

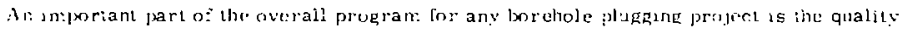
control pogran:. Personel from the grouting iranch of WES will particupale iu ali ficld activities

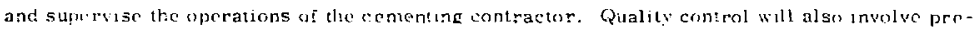
limary inspections of the requpment to be usod at the job site and in the bateh plant. Samples af all grouting will bo cobtained th addituon to samples of the hended materials beforo mixing. Samples of the mixed grouts will bo cast and tested at the fob-sth field laboratory for rapirf evaluation.

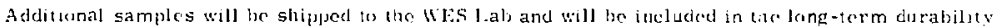
studies. Puysical properties of the ficle samples will be craluated for a tiata base of ficld raterals compared with laboratory-prepared specimens.

The fust fidd-learning actwity tunk place in Ockber 197, during tha plugging of ERDA 10 borchnle. IJata from the studies of these firja samples continue in be generalod. Samples casi at the surlace of the three different grout mixtures placed in a total of four plugs, cores from hardened grout in the bottom plug, and veturn grout furıng the placement of the third plug were obtained.

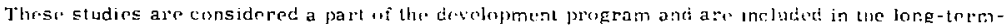
durabilicy testing. A report uf the dota from theso ficlei samples and the significance relaied to the development program is in preparation. 


\section{Refercences}

1. I. Herndon and D, K. Smuth, "Plugging Wells for Abandonment - A State-of-the-Art Study and Recommended Procedures, "Haliburton Services Sludy fur OWI, Y/OWI/Sulz-76/03068, Sipt. 1976.

2. 1. A. Boa, Jr., "73orehole Plugging Program (W'aste Disposal), Report 1, Initial Investigations and Preliminary Dala, " L.S. Army Engineer Waterways Experiment Station, Miscellaneous Paper C-78-1, Jan. 1979 (Sancliă Rripurl SANJ)77-7005).

3. "Borchole Sealing. "Dowell Div. of Dow Chemical, Jinal Rejxirt, Set, 31, 2!73, Subcontrart $78 X-159666$ for Union Carbide Corp., Nuclear Division, Nak Ridge, TN.

4. G. E. Rennuck, J. Pasini, I. É. Armstrong, and J. R, Alurams, "Demonstration of Jafety Plugging of Oil Wiells Penelrating Appalachian Coal Mines, "Technical Propress R^port-56, Jüurcau of Mines Health and Safety Rescarch Program, July 1972.

j. W. H. Kuenning, "Resistance of Portland Cement Mortar to Cliemical Attack - A Progress Report," PCA Research BuJletin 204, 1966.

6. G. J, Verbeck, "Field and Laboratory Studies of the Sulphate Resistance of Concrete," PCA Researcin Bulletın 227, 1967 .

7. F. M. Lea, The Chemistry of Cement and Concreic, Chomical Publishing Company, Inc., New York, NY, 1971.

8. I.. H. Tuthill, "Resistance to Chemical Attack," ASTTM Special Technical Publication No. $169-A, 1966$

0. W. O. Tynes, "Effects of Molst Curing of Concrete Made with Blended Cements of Pozzolans," U.S. Army Engineer Watcrways Experiment Station (WES), Technical Report C-69-6, April 1, 1972 .

10. "Portland-Pozzolan Cement Nacle with Tennessee Valley Authority Fly Ash, " U.S. Army Enginet: Waterways Experiment Station (WES), Technical Report No. 6-541, May 1960.

11. P. K. Mehti and Milos Polika, "Sulfate Resistance exf Expansive Concretes, "Publication SP-17. Ameriena Concrell listivite, 1975.

12. V. V. Mikhailov and S. I., L.1tver, "Expansive and Stressing Cements and Self-Stressed Reinfarced-Conerete Elements of Construction, "Moscow 1974. (Translated and issued as SANDT6-6010, Jec. 1975$)$.

13. B. Mather, "Unsolved Problems in Predicting the Behavinr of Coner ele," U. S. Army Corps of Engineers Waterways Experiment Station, Miscellaneous Paper No. 6-890, April 1967, 